\title{
Overview of Domestic Ideological-Political Education Research (2016-2020) Based on Citespace
}

\author{
Bingrong Li, Xiaobei Wang \\ School of Social Science and Humanities, North University of China, Taiyuan, China \\ Email: lisalbr@163.com
}

How to cite this paper: Li, B.R. and Wang, X.B. (2021) Overview of Domestic Ideological-Political Education Research (20162020) Based on Citespace. Open Access Library Journal, 8: e7984.

https://doi.org/10.4236/oalib.1107984

Received: September 20, 2021

Accepted: October 15, 2021

Published: October 18, 2021

Copyright $\odot 2021$ by author(s) and Open Access Library Inc.

This work is licensed under the Creative Commons Attribution International License (CC BY 4.0).

http://creativecommons.org/licenses/by/4.0/

\section{(c) (i) Open Access}

\begin{abstract}
By using the scientific measurement tool Citespace, this research systematically sorts out the important Ideological-Political Education research from 2016 to 2020, and conducts a comprehensive analysis from three aspects of basic trends, research hotspots and research content. It is found that Ideological-Political Education research has shown an upward trend as a whole, while gradually shifting from theoretical research to educational practice. The in-depth understanding of the connotation of Ideological-Political Education and the lack of empirical research are the main problems that currently exist. Therefore, future research should strengthen research on practical applications, evaluation mechanisms, etc., in order to give full play to the collaborative education goals of Ideological-Political Education.
\end{abstract}

\section{Subject Areas}

Curriculum Development

\section{Keywords}

Ideological-Political Education, Overview, Citespace, Ideological and Political Theory Courses

\section{Introduction}

The essence of Ideological-Political Education is to cultivate people with morality. The report of the 19th National Congress of the Communist Party of China pointed out that the fundamental task of establishing morality and cultivating people should be implemented. Education in the new era emphasizes that the purpose of education is to implement the three-in-one education concept of 
value shaping, ability training, and knowledge transfer. In December 2016, General Secretary Xi Jinping emphasized at the National University Ideological and Political Conference that various courses and ideological and political theory courses are in the same direction, forming a synergistic effect. The reform of "ideological-political education" also officially began in colleges and universities. On December 15, 2020, the conference for investigating and promoting the construction of Ideological-Political Education in colleges and universities shall be held to comprehensively promote the construction of Ideological-Political Education.

Foreign language courses are the closest to foreign cultures, ideologies, and customs. Therefore, it is increasingly important to understand the research and development of Ideological-Political Education in time to help promote the construction of Ideological-Political Education. This study reviews and sorts out the literature of domestic Ideological-Political Education in the past five years and summarizes the development trends and main research hot spots of Ideological-Political Education. This study also finds the deficiency of the current Ideological-Political Education, which provides some reference for future research.

\section{Research Methods and Data Sources}

Since the concept of Ideological-Political Education was put forward and promoted, experts and scholars have carried out a series of related research on this topic, and have obtained rich results. Citespace is a practical guide for mapping scientific literature, which can provide readers visual analysis of a topic. Based on the CNKI data analysis board of Citespace and the China Knowledge Network Measurement Visualization Analysis, this paper gives visual analysis of the development trend of Ideological-Political Education.

This study takes Ideological-Political Education as the theme to search in the China National Knowledge Infrastructure advanced search interface, the search time is set from 2016 to 2020, a total of 6000 relevant documents were retrieved. The retrieved documents were exported from CNKI in refwork format and then transformed by Citespace. The data suitable for Citespace analysis was obtained and then imported into Citespace again to obtain the co-occurrence graph of keywords, so as to intuitively see the research hotspots of Ideological-Political Education.

\section{The Research Status of Ideological-Political Education in Recent Years}

\subsection{Research Basic Trends}

A search was conducted on CNKI with the theme of Ideological-Political Education, and it can be seen from the results of CNKI metrological visualization analysis that in the past five years, domestic research on Ideological-Political Education has shown a rising trend. From 2016 to 2017, the development was relatively slow, and the number of articles published during this period increased 
by 117. 2018-2020 is a stage of rapid development, with 13,076 related papers published during this period. It can be seen that the research on Ideological-Political Education has attracted more and more scholars' attention (Figure 1).

At the same time, the time zone diagram of the key words of Ideological-Political Education was obtained by using the analysis of Citespace key words co-occurrence graph. As can be seen from Figure 2, the study of Ideological-Political Education started in 2017, the most prominent word is ideological education. By 2018, the most prominent word of the Ideological-Political Education study is moral education, which can be seen that the Ideological-Political Education began from theoretical research to educational practice. From 2019 to 2020, the most prominent word is teaching reform, the Ideological-Political Education research focus began to change to professional Ideological-Political Education.

\subsection{Research Hotspots}

The research hotspots of a certain topic can be seen through keywords (Figure 3).

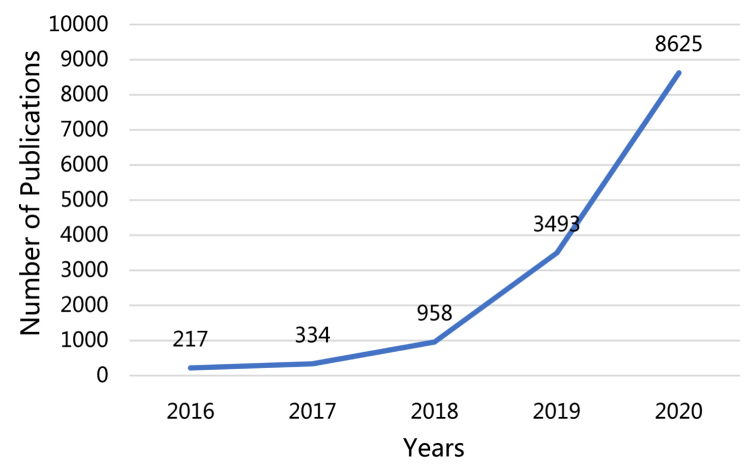

Figure 1. Basic trends.

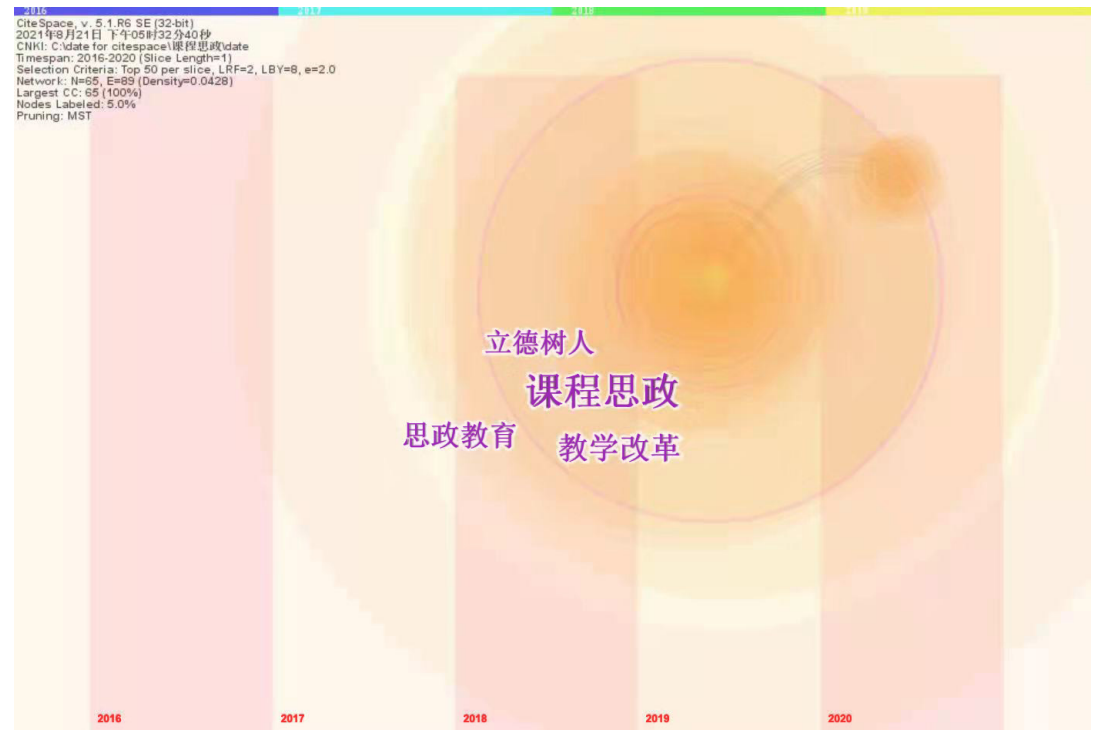

Figure 2. Keywords time zone diagram. 


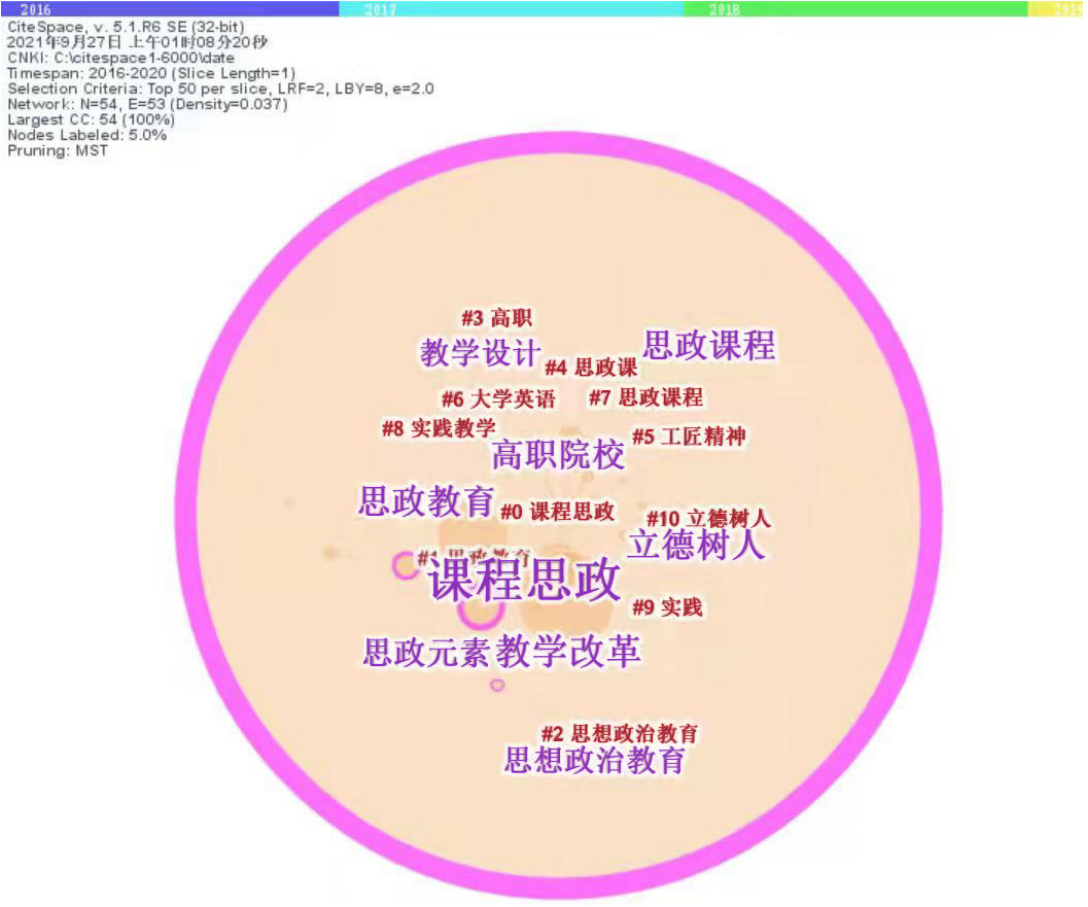

Figure 3. Keywords co-occurrence map.

By using the visual analysis of CiteSpace to analyze the Ideological-Political Education literature published by CNKI from 2016 to 2020, the top five keywords are: Ideological-Political Education, teaching reform, ideological and political education, moral education, Ideological and political theory courses (Table 1).

\subsection{Research Contents}

\subsubsection{Research on the Connotation of Ideological-Political Education}

The academic circles have different views on the understanding ofIdeological-Political Education. Qiu Weiguang [1] defined Ideological-Political Education from the perspective of Ideological-Political Education. He Yuhai [2] put forward Ideological-Political Education referred to the activities and process of Ideological-Political Education in all aspects and the whole process for students through the operation of the entire curriculum, that is, explicit and implicit courses, with the participation of all staff. Liu Jianjun [3] studied the connotation, characteristics and path of Ideological-Political Education, and showed that Ideological-Political Education was the ideological and political education of college students through curriculum construction and classroom teaching in colleges and universities. Tian Hongfen and Fu Hong [4] put forward that Ideological-Political Education was the conscious, planned and purposeful designed teaching links in the teaching process of various courses by ideological and political educators in the study of the practical path of integrating professional course teaching into Ideological-Political Education, and integrated Ideological-Political Education into the teaching process in an indirect or implicit way of 
Table 1. Top five high-frequency keywords in terms of number of posts.

\begin{tabular}{ccc}
\hline \multicolumn{3}{c}{ Top 5 high-frequency keywords } \\
\hline Keywords & Year of appearance & Frequency \\
\hline Ideological-Political Education & 2019 & 3842 \\
Teaching Reform & 2019 & 553 \\
Ideological and Political Education & 2019 & 375 \\
Moral Education & 2019 & 316 \\
Ideological and Political Theory Courses & 2019 & 282 \\
\hline
\end{tabular}

education. Wang Haiwei and Wang Bocheng [5] believed that Ideological-Political Education was an educational concept, rather than specifically referring to a certain course or several courses.

\subsubsection{Theoretical Research on the Implementation of Ideological-Political Education}

Qiu Renfu [6] gave a theoretical explanation of the same direction of Ideological-Political Education and Ideological and Political Theory Courses, and proposed that Ideological-Political Education can only be created for counterparts if it maintains the same direction as Ideological and Political Theory Courses, and finally realized the partnership and form a synergistic effect. Tian Hongfen and Fu Hong [4] also discussed the dialectical relationship between professional courses and Ideological-Political Education to strengthen Ideological-Political Education was a necessary move to practice Ideological-Political Education. Dai Lijuan [7] explored and studied the problems existing in the construction of Ideological-Political Education based on intensive English reading. From the perspective of collaborative education, Gao Xiwen [8] discussed the integration of professional courses and ideological and political courses in order to achieve a joint effort to educate people. Liu Shuhui [9] proposed the construction of the Internet + Ideological-Political Education model from the aspects of realistic demand, content construction and platform foundation.

\subsubsection{Research on the Practical Path of Ideological-Political Education} Zhang Yujie [10] analyzed how to use the ideological and political advantages of College English to implement Ideological-Political Education in college English courses. Zhang Ruixiang [11] pointed out in the research on the practice path of Ideological-Political Education in colleges and universities in the new era that teachers must first clarify the goals and requirements of Ideological-Political Education in colleges and universities, and innovated and improved the existing Ideological-Political Education models and systems, and effectively plan each link of the Ideological-Political Education in colleges and universities. Yu Guihua [12] analyzed the teaching practice path of Ideological-Political Education and proposed that the integration of Ideological-Political Education into the professional curriculum system should be carried out from multiple dimensions. 
Qiu Weiguang [13] believed that it was necessary to cultivate ability, impart knowledge, and integrate value guidance organically, adhere to the education guidance, and return to the foundation of the curriculum. Wu Yueqi [14] discussed the promotion of Ideological-Political Education from the three points of strengthening the ideological and political theory courses, promoting the construction of second classroom and third classroom, and exerting the function of campus culture in educating people.

\subsubsection{Key Issues in the Construction of Ideological-Political Education} Yang Xiaodong, Zhen Guohong, and Yao Liya [15] conducted research on the key issues that need to be resolved in the construction of Ideological-Political Education teaching materials. Xu Xinghua and Hu Daping [16] elaborated on several important issues that need to be grasped in advancing Ideological-Political Education. Gao Yan [17] explored the path of Ideological-Political Education reform by analyzing the key issues facing Ideological-Political Education. Han Xianzhou [18] elaborated on the key issues of Ideological-Political Education from the aspects of methodology, development, and practice, which has a certain significance in promoting the construction of a first-class socialist university.

\subsubsection{The Relationship between Ideological-Political Education and Ideological and Political Theory Courses}

Shi Shuchen [19] believed that both Ideological-Political Education and Ideological and Political Theory Courses are essentially educating people, but they have different emphases. It was necessary to correctly grasp the relationship between the two and give full play to their respective advantages to achieve the purpose of educating people. Zhao Jiwei [20] discussed the dialectical relationship between Ideological and Political Theory Courses and Ideological-Political Education from three aspects: concept, speech text, and practical exploration. Gao Deyi and Zong Aidong [21] believed that the ideological and political curriculum system of colleges and universities should be constructed with a trinity of ideological and political theory courses, comprehensive literacy courses, and professional courses.

In summary, experts and scholars have conducted research and exploration on Ideological-Political Education from different aspects and perspectives. In addition to the three aspects mentioned above, they also include the status of Ideological-Political Education and the significance of implementation. However, looking at the research of domestic scholars, the research on Ideological-Political Education is still in its infancy in China, and there are still some weakness such as a relatively single subject background and narrow fields.

\section{Research Reflections and Future Prospects}

\subsection{From the Subject Background of Ideological-Political Education}

At present, domestic research on Ideological-Political Education is mainly con- 
centrated in the field of ideological and political theory courses, and the combination of Ideological-Political Education with various professional disciplines is relatively weak. The school also pays more attention to the training of professional courses, and the attention and development of comprehensive quality courses are relatively weak. The subject teachers have a relatively single subject background. The teaching process is more of a single indoctrination by the teacher and cannot be diversified. At the same time, the level of teachers' ideological and theoretical knowledge is also uneven.

The well-known scholar Qiu Weiguang pointed out that in 2017, when studying the value meaning and generation path of Ideological-Political Education, he proposed that Ideological-Political Education focuses on construction, and teachers are the key. Therefore, the development of Ideological-Political Education in the future must first cultivate teachers' diversified disciplinary background, strengthen ideological and political theory literacy, and mobilize and organize teachers from all disciplines to actively and fully participate in providing key support for the development of Ideological-Political Education.

\subsection{From the Connection between Professional Courses and Ideological-Political Education Courses}

At this stage, most college courses are compulsory courses + situation and policy. However, in the actual teaching process, most of colleges focus on the exchange and discussion of compulsory professional courses, ignoring the situation and policy. Therefore, the lack of connection between Ideological-Political Education courses and professional courses, the natural integrate is not easy. In the future, the research of Ideological-Political Education should be integrated in both breadth and depth, so that professional courses and Ideological-Political Education courses can be exchanged and integrated naturally to ensure the implementation of Ideological-Political Education.

\subsection{From the Research Methods of Ideological-Political Education}

Most of them are based on the individual's understanding of the teaching model, so few of them are empirical research. Therefore, while strengthening theoretical research on Ideological-Political Education, it is necessary to continuously enrich and develop the essential connotation of Ideological-Political Education in practice, and form a set of multi-dimensional Ideological-Political Education system.

\subsection{From the Relevant Practice of Ideological-Political Education}

Ideological and Political Education lacks extensive practice. Ideological-Political Education is still in its infancy, and the main research and exploration is still in the elaboration. It does not integrate the relevant professional courses with political elements extensively in combination with the characteristics of the real classroom or the students, and construct the Ideological-Political Education system. Therefore, in the future research on Ideological-Political Education, it is 
necessary to accelerate the transformation of traditional teaching, gradually apply the new concept of Ideological-Political Education to the classroom, and continue to summarize and accumulate experience and provide more practical opinions.

\section{Conclusion}

By using the scientific measurement tool Citespace, this paper collects and analyses the relevant studies about Ideological-Political Education from 2016 to 2020. Then some deficiencies are pointed out. In the end, future researches are listed. Hopefully, it can contribute to the construction of Ideological-Political Education, help foster integrity and promote rounded development of people.

\section{Funding}

This paper is supported by the 2020 Shanxi Province Graduate Education and Teaching Reform Projects (No. 26) and the 2020 Shanxi Province Philosophy and Social Science Planning Projects (No. 2020YE019). It is also the phased research results of the Shanxi Province Research and Education Project for Overseas Students (No. HGKY2019076).

\section{Conflicts of Interest}

The authors declare no conflicts of interest.

\section{References}

[1] Qiu, W.G. (2017) The Value Implication and Generation Path of Ideological-Political Education. Ideological and Theoretical Education, No. 7, 10-14.

[2] He, Y.H. (2019) Exploration on the Essential Connotation and Realization Path of "Ideological-Political Education". Leading Journal of Ideological and Theoretical Education, No. 10, 130-134.

[3] Liu, J.J. (2020) Ideological-Political Education: Connotation, Characteristics and Path. Educational Research, 41, 28-33.

[4] Tian, H.F. and Fu, H. (2018) Ideological-Political Education: The Practical Path of Integrating the Teaching of Professional Courses in Colleges and Universities into Ideological and Political Education. Future and Development, 42, 99-103.

[5] Wang, H.W. and Wang, B.C. (2018) On the Core Essentials and Practical Paths of Ideological-Political Education in Colleges and Universities. The Party Building and Ideological Education in Schools, No. 14, 32-34.

[6] Qiu, R.F. (2018) Theoretical Explanation of "Ideological-Political Education" and "Ideological and Political Theory Course" in the Same Direction. Studies in Ideological Education, No. 4, 109-113.

[7] Dai, L.J. (2020) Exploration on Construction and Path of Ideological-Political Education-Taking the Course of "English Intensive Reading" as an Example. Yangtze River Series, No. 16, 89-142.

[8] Gao, X.W. (2017) Research on the Working Mode of Ideological-Political Education Based on Collaborative Education-Taking Shanghai University Reform Practice as an Example. The Party Building and Ideological Education in Schools, No. 24, 
18-20.

[9] Liu, S.H. (2017) Theoretical Research on the Construction of "Internet + Ideological-Political Education” Mode. China Higher Education, No. Z3, 15-17.

[10] Zhang, Y.J. (2018) Research on the Implementation of Ideological-Political Education in College English Curriculum. English on Campus, No. 36, 82-83.

[11] Zhang, R.X. (2020) Research on the Practice of Ideological-Political Education in Colleges and Universities in the New Era. The Science Education Article Collects, No. 4, 52-53.

[12] Yu, G.H. (2020) Analysis of Teaching Practice Path of "Ideological-Political Education". Theory and Practice of Education, No. 15, 27-29.

[13] Qiu, W.G. (2018) On the Internal Regulations and Implementation Focus of Ideological-Political Education. Ideological and Theoretical Education, No. 8, 62-65.

[14] Wu, Y.Q. (2018) On the Three Focal Points of Promoting "Ideological-Political Education" in Colleges and Universities. The Party Building and Ideological Education in Schools, No. 1, 67-69.

[15] Yang, X.D., Zhen, G.H. and Yao, L.Y. (2020) Key Issues in the Construction of Ideological-Political Education Textbooks for Professional Courses in Applied Universities. Journal of National Academy of Education Administration, No. 5, 68-75.

[16] Xu, X.H. and Hu, D.P. (2021) Key Issues in Advancing Ideological-Political Education. China University Teaching, No. 5, 60-64.

[17] Gao, Y. (2017) Ideological-Political Education-Key Issues and Solutions of Ideological-Political Education Construction. China Higher Education, No. Z3, 11-14.

[18] Han, X.Z. (2019) Key Issues in Deepening the Construction of "Ideological-Political Education”. Journal of Beijing Union University (Humanities and Social Sciences), 17,7 .

[19] Shi, S.C. (2018) Correctly Grasp the Relationship between "Ideological-Political Education" and "Ideological and Political Theory Course". Ideological and Theoretical Education, No. 11, 57-61.

[20] Zhao, J.W. (2018) On the Dialectical Relationship between "Ideological and Political Theory Course" and "Ideological-Political Education". Study of Ideological and Political Course, No. 5, 51-55.

[21] Gao, D.Y. and Zong, A.D. (2017) From Ideological and Political Theory Course to Ideological-Political Education: Constructing the Curriculum System of Ideological and Political Education in Colleges and Universities from a Strategic Height. China Higher Education, No. 1, 43-46. 